\title{
The effect of nitrogen and the method of application on yield and quality of broccoli
}

\author{
A.P. EVERAARTS ${ }^{1, *}$ AND P. DE WILLIGEN ${ }^{2}$ \\ ${ }^{1}$ Applied Research for Arable Farming and Field Production of Vegetables (PAV), \\ P.O. Box 430, NL-8200 AK Lelystad, The Netherlands \\ ${ }^{2}$ Research Institute for Agrobiology and Soil Fertility (AB), P.O. Box 14, NL-6700 AA \\ Wageningen, The Netherlands \\ * Corresponding author (fax: + 31-320-230479; e-mail: a.p.everaarts@ pav.agro.nl)
}

Received 15 May 1998; accepted 31 May 1999

\begin{abstract}
The effects of the amount and the method of nitrogen application on yield and quality of broccoli were studied during three seasons. Different amounts of nitrogen fertilizer were applied broadcast or band placed at planting. Band placement of fertilizer increased the yield in five out of eight experiments. Application of nitrogen results in larger heads. No relationship was found between mineral nitrogen at planting and optimum nitrogen applications because of the narrow range of amounts of mineral nitrogen at planting. Split application had no or a negative effect on yield and therefore is not recommended. For optimum yields it is recommended to apply $270 \mathrm{~kg}$ of nitrogen per hectare, minus the mineral nitrogen in the soil layer $0-60 \mathrm{~cm}$ at planting, band placed at planting. For broadcast application $275 \mathrm{~kg}$ of nitrogen minus mineral nitrogen applied at planting is recommended, but yield will be lower as compared with band placement of fertilizer.
\end{abstract}

Keywords: broccoli, Brassica oleracea var. italica, soil mineral nitrogen, nitrogen fertilizer, fertilizer band placement, split application, quality, yield

\section{Introduction}

Optimum yields of broccoli (Brassica oleracea var. italica) have been obtained at nitrogen fertilizer applications of $175-250 \mathrm{~kg} \mathrm{ha}^{-1}$ at planting (Cutcliffe et al., 1968; Greenwood et al., 1980). Dufault \& Waters (1985) and Kowalenko \& Hall (1987) found increases in yield with an increase in nitrogen application from 168 to 224 and 125 to $250 \mathrm{~kg} \mathrm{ha}^{-1}$ respectively. Kahn et al. (1991), however, found no effect on yield of nitrogen applications above $97 \mathrm{~kg} \mathrm{ha}^{-1}$ in three out of four experiments. Zebarth et al. (1995) obtained the maximum yield with application of around 440-550 kg ha-1 nitrogen, while Goodlass et al. (1997) found highest yields at $210-300 \mathrm{~kg} \mathrm{ha}^{-1}$ nitro- 
gen. Toivonen et al. (1994) reported that $125-250 \mathrm{~kg} \mathrm{ha}^{-1}$ nitrogen as a split application was optimum for a certain head size. Under conditions conducive for head rot, high rates of nitrogen may promote the occurrence of head rot and thereby reduce marketable yield (Everaarts, 1994). Differences in climatic conditions, in product quality and size requirements and especially in mineral nitrogen availability, are likely to be responsible for the variation in the rate of nitrogen fertilization to obtain maximum yields. In the Netherlands $300 \mathrm{~kg} \mathrm{ha}^{-1}$ nitrogen is recommended, in a split application, to obtain optimum broccoli yields (Sieling, 1992). Two hundred fifty kg $\mathrm{ha}^{-1}$ nitrogen, minus the mineral nitrogen in the soil layer $0-60 \mathrm{~cm}$, with a minimum of $50 \mathrm{~kg} \mathrm{ha}^{-1}$, should be broadcasted at planting, followed by $50 \mathrm{~kg} \mathrm{ha}^{-1}$ nitrogen applied six weeks after planting.

Band placement of nitrogen fertilizer has been referred to as a possible method to increase the yield in Brassica vegetables (Everaarts, 1993b). To investigate whether band placement of nitrogen fertilizer with broccoli could result in either higher yields or similar yields with a lower nitrogen supply, eight experiments were carried out during three seasons, in which the effects of the amount of nitrogen and the method of application, broadcast vs. band placed, on yield and quality of broccoli were studied. In addition observations were made on the nitrogen in the crop and soil at harvest and on the loss of nitrogen from the crop+soil system. The results of these observations are presented in a forthcoming paper. The present paper reports on the results of nitrogen fertilization on yield and quality.

\section{Materials and methods}

\section{General}

The experiments were carried out from 1990 to 1992 in fields of a broccoli farmer in a major broccoli cultivation area (Andijk) and at the research station at Lelystad (Table 1). The cultivar Emperor was used. Soil chemical properties of the experimental fields are given in Table 2. Soil classification is according to soil clay content (Steur \& Heijink, 1991). Soil cultivation as preparation for planting was always

Table 1. Location, planting date and harvest period of the experiments.

\begin{tabular}{lllll}
\hline Experiment & Location & Planting date & \multicolumn{2}{c}{ Days after planting } \\
\cline { 3 - 4 } & & & First harvest & Last harvest \\
& & & 58 & 64 \\
1 & Andijk & $16-05-1990$ & 56 & 67 \\
2 & Lelystad & $18-05-1990$ & 60 & 69 \\
4 & Andijk & $15 / 16-05-1991$ & 59 & 70 \\
5 & Lelystad & $21-05-1991$ & 53 & 69 \\
6 & Lelystad & $15-07-1991$ & 59 & 55 \\
7 & Andijk & $22-07-1991$ & 54 & 50 \\
\hline
\end{tabular}


Table 2. Chemical properties of the soil $(0-30 \mathrm{~cm})$.

\begin{tabular}{lllllll}
\hline $\begin{array}{l}\text { Expe- } \\
\text { riment }\end{array}$ & $\mathrm{pH}-\mathrm{KCl}$ & $\begin{array}{l}\text { Organic } \\
\text { matter }(\%)\end{array}$ & $\begin{array}{l}\text { Clay } \\
(<2 \mu \mathrm{m}, \%)\end{array}$ & $\begin{array}{l}\mathrm{Pw} \\
\left(\mathrm{mg} \mathrm{l}^{-1} \mathrm{P}_{2} \mathrm{O}_{5}\right)\end{array}$ & $\begin{array}{l}\mathrm{K}-\mathrm{ox} \\
\left(\mathrm{mg} 100 \mathrm{~g}^{-1} \mathrm{~K}_{2} \mathrm{O}\right)\end{array}$ & Soil type \\
1 & 7.5 & 1.9 & 17.0 & 61 & 28 & light sandy clay \\
2 & 7.5 & 1.9 & 16.6 & 60 & 28 & light sandy clay \\
3 & 7.3 & 3.1 & 20.4 & 64 & 31 & heavy sandy clay \\
4 & 7.4 & 1.9 & 13.6 & 45 & 21 & light sandy clay \\
5 & 7.6 & 1.9 & 13.4 & 60 & 21 & light sandy clay \\
heavy sandy clay \\
6
\end{tabular}

carried out shortly before planting. Module raised transplants were used and planting was done by hand. Plots contained 56 plants at a planting distance of $0.50 \times 0.45$ m. Nitrogen was applied as calcium ammonium nitrate $(27 \% \mathrm{~N})$. During the harvest period (Table 1) three to six harvests of terminal heads were carried out. Heads were graded in Qualities I and II, and unmarketable (Anonymous, 1977). Heads of Quality I and II were further sorted in the diameter classes 4-8, 8-12 and >12 cm head diameter and weighed. At six days after planting pigeons severely damaged the crop in Experiment 4. Crop growth only slowly resumed.

\section{Experimental procedures}

The experiments were laid out in a randomized complete block design with 12 (Experiments 1-6) or 11 (Experiments 7 and 8) treatments in four replicates. Before planting samples consisting of approximately twenty cores were taken across the diagonal of each replicate of the soil layers $0-30$ and $30-60 \mathrm{~cm}$ of the experimental fields, to determine the amount of mineral nitrogen (Nmin) (Table 3). Mineral nitrogen was determined colorimetrically after extraction of soil with $\mathrm{KCl}$ (Vierveijzer et

Table 3. The amount of mineral nitrogen in the soil before planting and the highest amount of nitrogen applied $\left(\mathrm{kg} \mathrm{ha}^{-1}\right)$.

\begin{tabular}{|c|c|c|c|c|}
\hline \multirow[t]{3}{*}{ Experiment } & \multicolumn{3}{|c|}{ Mineral nitrogen } & \multirow{3}{*}{$\begin{array}{l}\text { Highest amount } \\
\text { of nitrogen applied } \\
\text { at planting }(4 N)\end{array}$} \\
\hline & \multirow[t]{2}{*}{ Sampling date } & \multicolumn{2}{|c|}{ Soil layer (cm) } & \\
\hline & & $0-30$ & $0-60$ & \\
\hline 1 & 02-05-1990 & 30 & 52 & 204 \\
\hline 2 & $02-05-1990$ & 20 & 32 & 224 \\
\hline 3 & 02-05-1991 & 26 & 49 & 204 \\
\hline 4 & 02-05-1991 & 21 & 35 & 220 \\
\hline 5 & 03-07-1991 & 17 & 39 & 212 \\
\hline 6 & 02-07-1991 & 25 & 45 & 212 \\
\hline 7 & 27-04-1992 & 24 & 60 & 344 \\
\hline 8 & 27-04-1992 & 16 & 30 & 372 \\
\hline
\end{tabular}


al., 1979). At planting in each experiment $0, N, 2 N, 3 N$ and $4 N \mathrm{~kg}$ of nitrogen per hectare was applied (Table 3) and there was a split application of $2 N+N$. The highest nitrogen availability at planting was approximately 250 (Experiments 1-6) and 400 (Experiments 7 and 8) $\mathrm{kg}$ per hectare for the soil layer 0-60 cm. The second application with the split application was applied at 30, 28, 24, 41, 36, 25, 28 or 27 days after planting for Experiments 1 to 8 respectively. Nitrogen was applied either broadcast or band placed. On broadcast plots the fertilizer was lightly raked in. With band placement the fertilizer was placed by hand in a hand-drawn furrow, about $5 \mathrm{~cm}$ on one side of the row, about $5 \mathrm{~cm}$ deep, after which the furrow was closed again. Plots of the no-nitrogen treatments in Experiments 1-6 were lightly raked or furrows were drawn and closed. The second fertilizer application with the split application was applied broadcast.

Statistical analysis was carried out through analysis of variance and regression analysis with the Genstat 5 programme (Genstat 5 Committee, 1993). For Experiments 7 and 8 the significance indicated in the Tables only applies to treatments in which nitrogen was applied.

\section{Results}

\section{Percentage of marketable heads harvested and earliness of harvest}

The percentage of plants that produced a marketable head ranged from 84 to 100 percent between treatments (data not shown). In Experiments 1, 7 and 8 withholding of nitrogen resulted in a significantly reduced percentage of marketable heads harvested. Nitrogen application therefore appears essential to secure the maximum percentage of marketable heads. In Experiments 3 and 7 band placement of nitrogen resulted in a respectively one and four percent higher number of heads harvested. Split application had no effect on the percentage of marketable heads harvested.

In a number of experiments it was found that application of nitrogen increased earliness of harvest. Band placement sometimes also increased earliness of harvest, but it also delayed harvest once. Because of the only small effects and the usually limited length of the harvest period (Table 1), the effects on earliness are not considered to be of importance for the further treatment of the data.

\section{Yield}

Apparently as a result of an early pigeon damage to the crop, marketable yields (Quality I + II) in Experiment 4 were low in comparison to the yields in the other experiments (Table 4). In all experiments the yield increased with nitrogen application. In Experiments 1, 2, 5, 7, and 8 the average yield also increased with band placement of nitrogen. Especially in Experiment 7 the higher number of heads harvested with band placement will have contributed to this result. Split application of nitrogen usually had no, or a negative (Experiments 3 and 6), effect on the yield and therefore is not to be recommended. 


\section{EFFECT OF NITROGEN ON YIELD AND QUALITY OF BROCCOLI}

Table 4. Marketable yield (Quality I + II, $\mathrm{t} \mathrm{ha}^{-1}$ ).

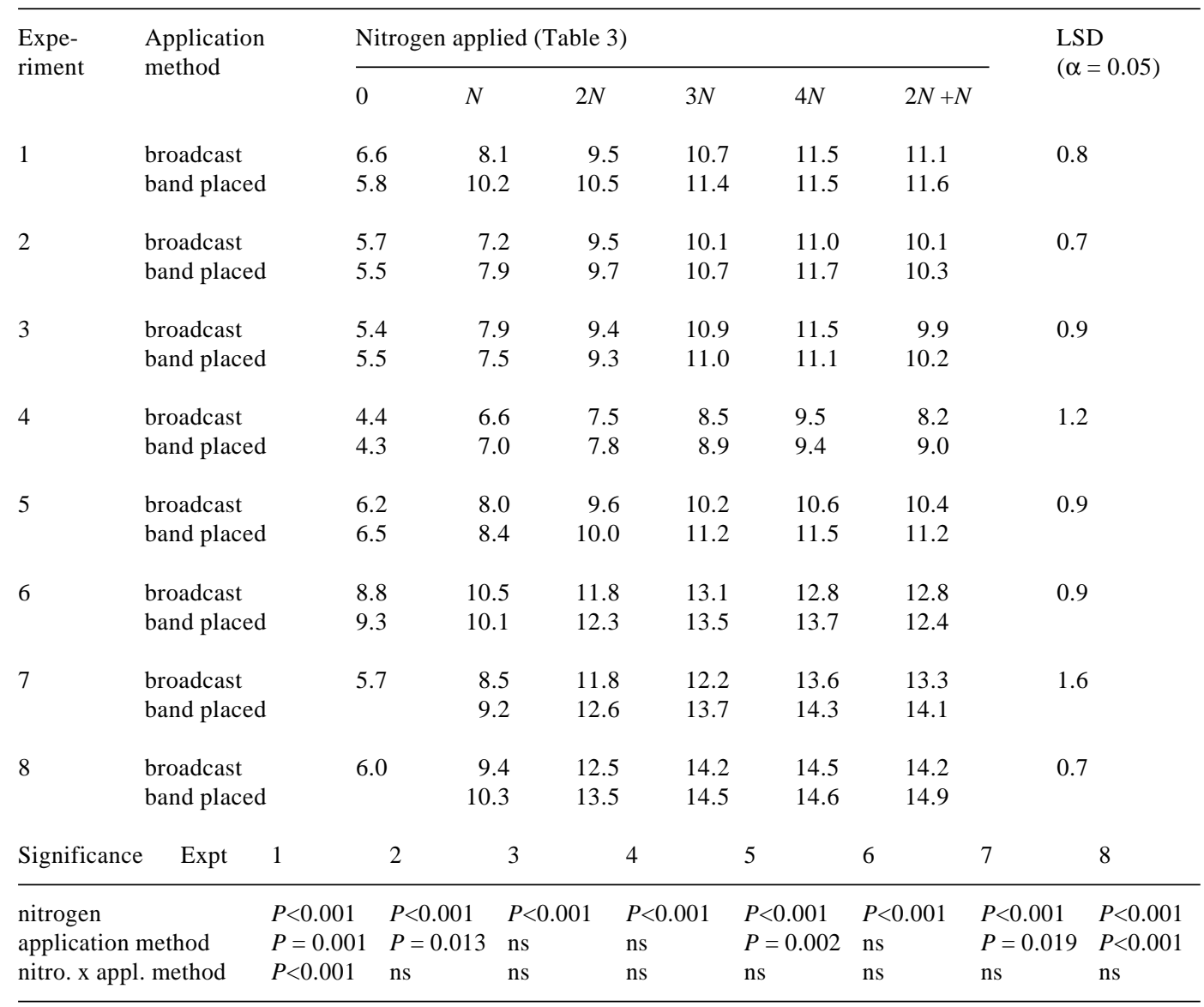

\section{Quality and grading}

The effects of the treatments on the quality of the heads was evaluated as the percentage Quality I of the weight of the marketable heads (Quality I + II). The percentage Quality I was significantly positively influenced by nitrogen application in five of the eight experiments (Table 5). The method of application did not influence the quality of the harvested product. Split application usually had no effect on quality.

In all experiments the portion of heads with a diameter of $12 \mathrm{~cm}$ or more, as a percentage of the number of marketable heads, strongly increased with application of nitrogen (data not shown). In three experiments band placement further increased this percentage. Split application usually had no effect and sometimes a negative effect on the percentage of heads with a diameter of $12 \mathrm{~cm}$ or more. 
Table 5. The percentage Quality I of the weight of the marketable heads.

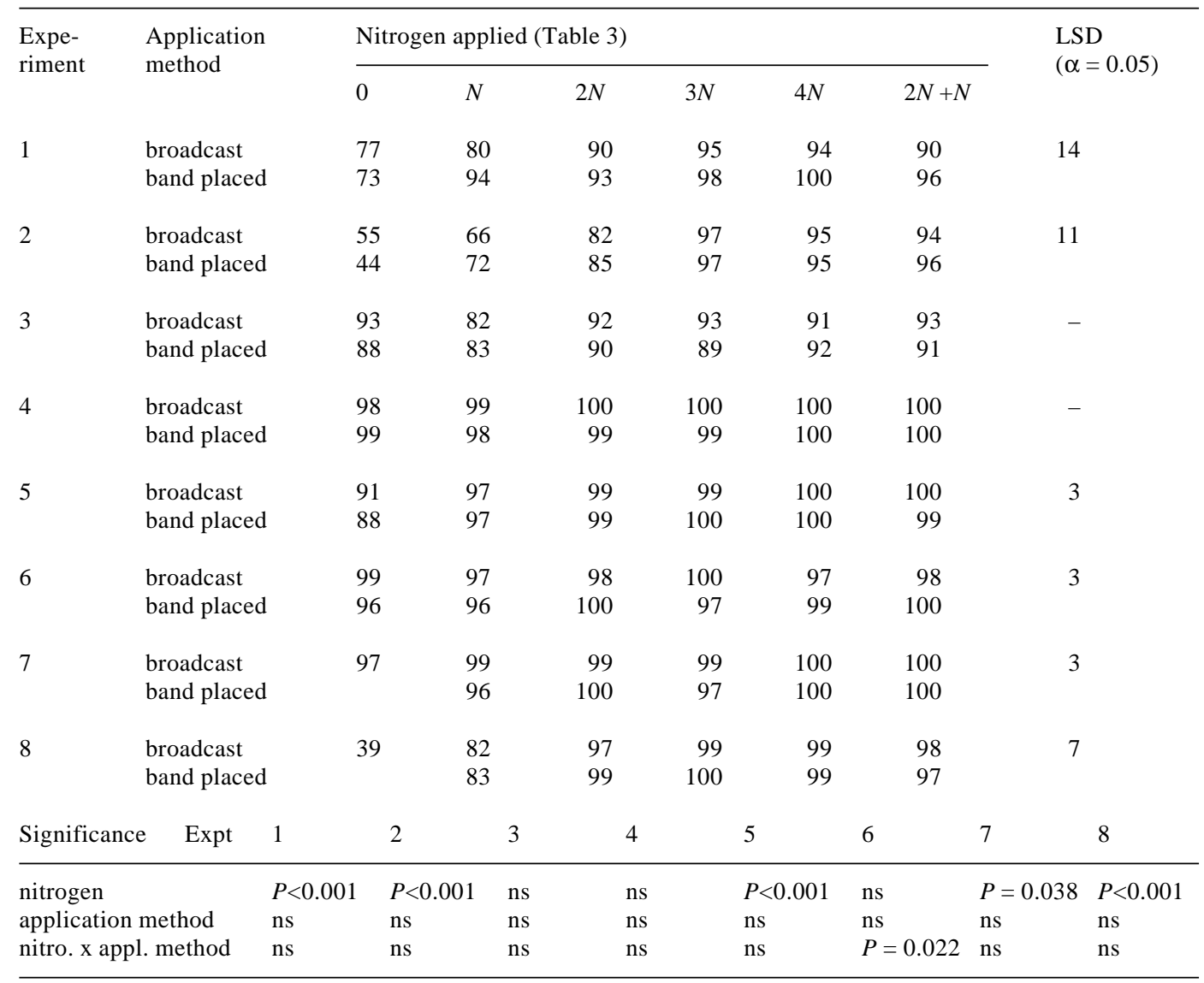

\section{Determination of optimum nitrogen application}

To determine the optimum nitrogen application the yield data from Table 4 were used, excluding the yields with split application. Yields were converted to relative yields to exclude other factors than nitrogen that may have influenced the yield. The response in yield to nitrogen for all experiments combined was described with an exponential function (Figure 1). Without taking mineral nitrogen at planting into account, the percentage variance accounted for in the response was already quite high: $87 \%$. There was a significant response $(P<0.001)$ to nitrogen applied and a significant response $(P=0.034)$ to the method of application, without interaction between the two. With the same amount of nitrogen applied the yield was higher with band placement as compared to broadcast application. The residual sum of squares, as a measure of the degree of fit, decreased only slightly and the percentage of variance accounted for hardly increased, when the amount of mineral nitrogen in the soil layer 


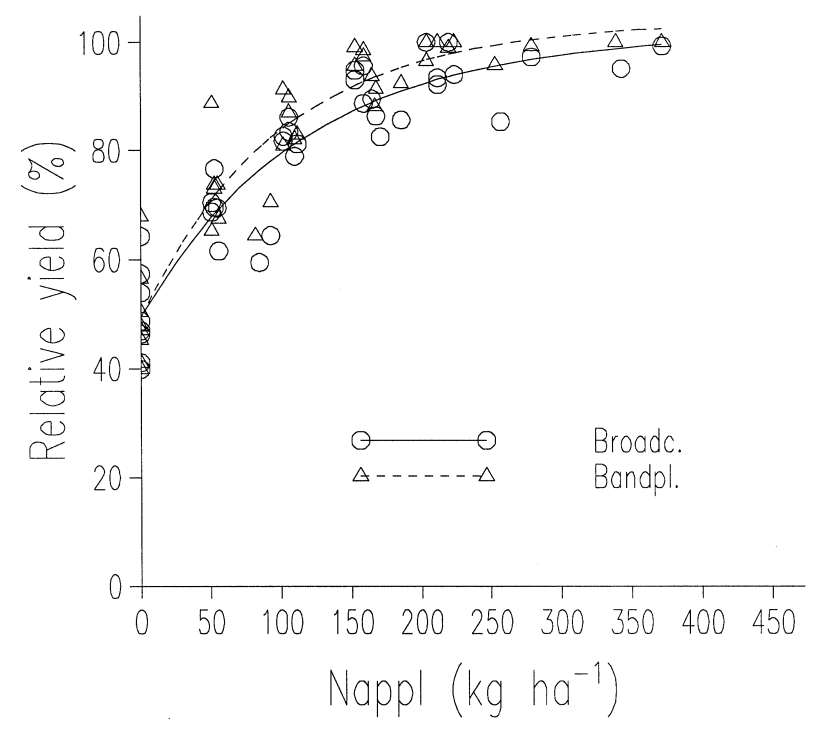

Figure 1. Relative yield for the amount of nitrogen applied ( $\mathrm{N}$ appl) with broadcast application and band placement of fertilizer.

0-30 $\mathrm{cm}$ at planting was included in the amount of nitrogen available. This is obvious given the low amounts of mineral nitrogen in this soil layer at planting and the limited variation in these amounts beween the experiments (Table 3). Inclusion of the mineral nitrogen in the soil layer $0-60 \mathrm{~cm}$ in the response even increased the residual sum of squares. However, in all situations there was a significant positive response in yield to band placement.

For each experiment separately and for both methods of application, the nitrogen application rate to obtain the optimum yield was determined with the linear plateau model (Uhte, 1990; Everaarts \& Van Den Berg, 1996) (Table 6). The application rates were then related to the amounts of mineral nitrogen in the soil layers $0-30$ or $0-60 \mathrm{~cm}$ at planting. However, no significant linear relationship between these application rates and the mineral nitrogen at planting in the two soil layers could be established. Exclusion of Experiment 2, where no clear optimum application rate was reached as highest yields differed significantly, and Experiment 4 because of exceptionally low yields, did not improve the relationships.

It thus was shown that band placement resulted in higher yields, but no linear relation was found between optimum nitrogen application rates in each experiment and the amount of mineral nitrogen at planting. However, observations at the root system of broccoli (Thorup-Kristensen, 1993; Everaarts et al., 1996) make it likely that broccoli uses the mineral nitrogen in the soil layer $0-60 \mathrm{~cm}$. The amount of nitrogen required to obtain optimum yields (Nopt) can then be defined as the sum of the calculated optimum nitrogen application rate for each experiment (Table 6, excluding Experiment 4 because of exceptionally low yield) and the amount of mineral nitrogen at planting in the experiments (Table 3). A cumulative frequency distribution of Nopt was made (Figure 2). A logistic curve was fitted through the points. From this figure it can be read what is the probability that a certain applied amount of fertilizer 
Table 6. Calculated nitrogen application rate to obtain optimum yield with the linear plateau response model for each experiment (Nappl), the corresponding yield and the variance accounted for. Values between brackets represent the standard error (s.e.).

\begin{tabular}{|c|c|c|c|c|c|c|}
\hline \multirow[t]{3}{*}{ Expt } & \multicolumn{6}{|c|}{ Application method } \\
\hline & \multicolumn{3}{|l|}{ Broadcast } & \multicolumn{3}{|c|}{ Band placement } \\
\hline & $\begin{array}{l}\text { Nappl } \\
\left(\mathrm{kg} \mathrm{ha}^{-1}\right)\end{array}$ & $\begin{array}{l}\text { Yield } \\
\left(\mathrm{t} \mathrm{ha}^{-1}\right)\end{array}$ & $\begin{array}{l}\text { Variance } \\
\text { accounted } \\
\text { for }(\%)\end{array}$ & $\begin{array}{l}\text { Nappl } \\
\left(\mathrm{kg} \mathrm{ha}^{-1}\right)\end{array}$ & $\begin{array}{l}\text { Yield } \\
\left(\mathrm{t} \mathrm{ha}^{-1}\right)\end{array}$ & $\begin{array}{l}\text { Variance } \\
\text { accounted } \\
\text { for }(\%)\end{array}$ \\
\hline 1 & $180 \quad(6)$ & 11.5 & 100 & $62 \quad(9)$ & 11.1 & 95 \\
\hline 2 & $147 \quad(22)$ & 10.6 & 95 & $149 \quad(21)$ & 11.2 & 95 \\
\hline 3 & $144 \quad(17)$ & 11.2 & 97 & $148 \quad(3)$ & 11.1 & 100 \\
\hline 4 & $103 \quad(53)$ & 8.5 & 74 & $90 \quad(31)$ & 8.7 & 83 \\
\hline 5 & 130 & 10.4 & 99 & 145 & 11.4 & 99 \\
\hline 6 & $144 \quad(10)$ & 13.0 & 99 & 163 (19) & 13.7 & 96 \\
\hline 7 & $204 \quad(27)$ & 12.9 & 95 & $200 \quad(10)$ & 14.0 & 99 \\
\hline 8 & $237 \quad(7)$ & 14.4 & 100 & $208 \quad(10)$ & 14.6 & 99 \\
\hline
\end{tabular}

plus mineral nitrogen at planting, is equal or higher than the amount of nitrogen required to obtain optimum yield. It is shown that in most situations $(P=0.95) 275 \mathrm{~kg}$ of nitrogen minus mineral nitrogen at planting $(0-60 \mathrm{~cm})$ applied broadcast or 268 $\mathrm{kg}$ minus mineral nitrogen band placed will be sufficient for optimum yields. It is concluded that $270 \mathrm{~kg}$ of nitrogen per hectare minus mineral nitrogen at planting, applied band placed at planting, is to be recommended for optimum yields of broccoli. For broadcast application $275 \mathrm{~kg}$ of nitrogen minus mineral nitrogen is recommended, but yield with broadcast application is lower.

\section{Discussion}

With cauliflower and white cabbage a linear relation was found between the optimum nitrogen application and the amount of mineral nitrogen in the soil layer 0-60 cm at planting (Everaarts \& De Moel, 1995; Everaarts \& De Moel, 1998). Probably the main reason for not finding such a relation for broccoli are the low amounts of mineral nitrogen at planting in the present experiments and the limited variation in amounts between the experiments. Because of this, the range of values in mineral nitrogen in which the relation with the optimum application should be established is too small. In general, because of the, sometimes large (Neeteson and Wadman, 1987), error around the estimate of an optimum application, a wide range of mineral nitrogen values is needed, to be able to establish a relationship between the optimum nitrogen fertilizer application and the amount of mineral nitrogen at planting.

Thorup-Kristensen (1993) showed that broccoli is able to root deeper than $1 \mathrm{~m}$ and that rooting depth is influenced by the distribution of mineral nitrogen in the soil. Observations with pinboards at fifty days after planting in Experiment 5 showed that average rooting density at $45-55 \mathrm{~cm}$ depth was around $0.6 \mathrm{~cm}$ per $\mathrm{cm}^{3}$, for both broadcast and band application of $2 N \mathrm{~kg}$ of nitrogen per hectare (Everaarts et al., 

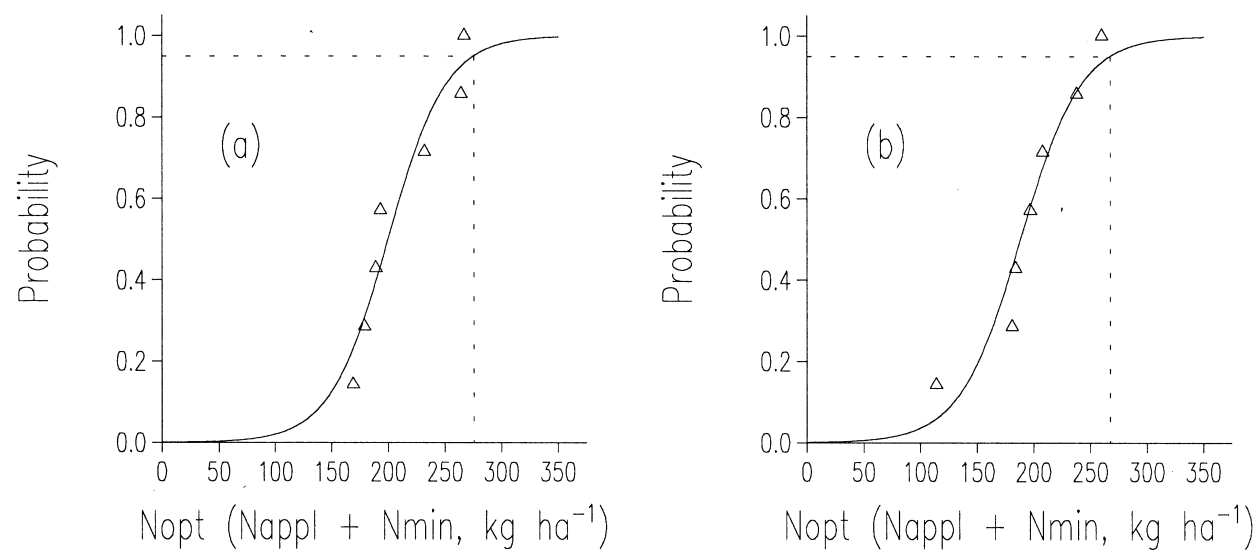

Figure 2. Cumulative frequency distribution of the amount of nitrogen required to obtain optimum yields (Nopt) (Experiment 4 excluded), with broadcast application (a) and band placement (b). The dotted line indicates $P=0.95$.

1996). This rooting density is sufficient for uptake of nitrogen, even at low amounts of available nitrogen (De Willigen \& Van Noordwijk, 1987). Based on these observations it is concluded that broccoli is able to utilise the mineral nitrogen in the soil layer $0-60 \mathrm{~cm}$. Also the low amounts of mineral nitrogen found at harvest with low amounts of nitrogen applied (Everaarts et al., 1996), support this conclusion.

Band placement of nitrogen fertilizer has been mentioned as a possible strategy to increase the yield of Brassicas or to obtain the same yield with less fertilizer (Everaarts, 1993b). However, for cauliflower and white cabbage it was concluded that band placement cannot be recommended (Everaarts \& De Moel, 1995; Everaarts \& De Moel, 1998). In the analysis of the combined experiments with broccoli a consistent positive effect of band placement on yield was found. This effect could possibly be based on effects with applications in the suboptimal range. However, there still is a band placement effect with optimum applications in the range of 200 to $250 \mathrm{~kg}$ ha $^{-1}$ nitrogen as determined in Experiments 7 and 8. In this range, the same amount of nitrogen applied band placed, results in four to five percent higher yields than with broadcast application.

In general plant uptake of nitrogen per unit of root mass would be highest shortly after planting. Band placement of fertilizer in that situation could improve nitrogen uptake. However, no obvious differences in crop growth between treatments were observed in the field shortly after planting, nor later in the crop cultivation period. The reason why band placement has a positive effect on yield with broccoli and not, or not consistently, with cauliflower and white cabbage, is perhaps related to the fact that broccoli, as compared to the other two crops, has a shorter growth period and a comparatively high uptake of nitrogen (Everaarts, 1993a), which continues up to harvest (Shelp \& Liu, 1992). Especially in the period shortly before harvest the nitrogen uptake rate of broccoli is high (Shelp \& Liu, 1992) and under these conditions band placement possibly improves nitrogen availability, resulting in yield increases. 
The recommended nitrogen application rate in the Netherlands for broccoli is 300 $\mathrm{kg} \mathrm{ha}^{-1}$, minus the mineral nitrogen in the soil layer $0-60 \mathrm{~cm}$ at planting, in a split application (Sieling, 1992). Based on the present experiments it is now recommended to apply $270 \mathrm{~kg}$ of nitrogen per hectare minus mineral nitrogen in the soil layer $0-60 \mathrm{~cm}$ at planting, band placed at planting. For broadcast application $275 \mathrm{~kg}$ of nitrogen minus mineral nitrogen is recommended, but yield with broadcast application is lower as compared to band placement.

\section{Acknowledgements}

We thank W. Van Den Berg (PAV, Lelystad) for statistical assistance and Dr. R. Booij (AB-DLO, Wageningen) and Dr. C. Rahn (HRI, Wellesbourne) for their critical comments on the manuscript.

\section{References}

Anonymous, 1977. Quality prescriptions fresh vegetables and fresh fruits (in Dutch). Produktschap voor Groenten en Fruit, Den Haag.

Cutcliffe, J.A., D.C. Munro \& D.C. MacKay, 1968. Effect of nitrogen, phosphorus, potassium, and manure on terminal, lateral, and total yields and maturity of broccoli. Canadian Journal of Plant Science 48: 439-446.

De Willigen, P. \& M. van Noordwijk, 1987. Roots, plant production and nutrient use efficiency. PhD Thesis, Wageningen, $282 \mathrm{pp}$.

Dufault, R.J. \& L. Waters Jr., 1985. Interaction of nitrogen fertility and plant populations on transplanted broccoli and cauliflower yields. HortScience 20: 127-128.

Everaarts, A.P., 1993a. General and quantitative aspects of nitrogen fertilizer use in the cultivation of Brassica vegetables. Acta Horticulturae 339: 149-160.

Everaarts, A.P., 1993b. Strategies to improve the efficiency of nitrogen fertilizer use in the cultivation of Brassica vegetables. Acta Horticulturae 339: 161-173.

Everaarts, A.P., 1994. Nitrogen fertilization and head rot in broccoli. Netherlands Journal of Agricultural Science 42: 195-201.

Everaarts, A.P. \& C.P. De Moel, 1995. The effect of nitrogen and the method of application on the yield of cauliflower. Netherlands Journal of Agricultural Science 43: 409-418.

Everaarts, A.P. \& C.P. De Moel, 1998. The effect of nitrogen and the method of application on the yield and quality of white cabbage. European Journal of Agronomy 9: 203-211.

Everaarts, A.P., C.P. De Moel \& P. De Willigen, 1996. Nitrogen fertilization and nutrient uptake of broccoli (in Dutch). Report 216. Proefstation voor de Akkerbouw en de Groenteteelt in de Vollegrond, Lelystad, $67 \mathrm{pp}$.

Everaarts, A.P. \& W. Van Den Berg, 1996. A comparison of three nitrogen response models for cauliflower. Acta Horticulturae 428: 171-179.

Genstat 5 Committee, 1993. Genstat 5 Release 3 Reference Manual. Clarendon Press, Oxford, 796 pp.

Goodlass, G., C. Rahn, M.A. Shepherd, A.G. Chalmers and F.M. Seeney, 1997. The nitrogen requirement of vegetables: Comparisons of yield response models and recommendation systems. Journal of Horticultural Science 72: 239-254.

Greenwood, D.J., T.J. Cleaver, M.K. Turner, J. Hunt, K.B. Niendorf \& S.M.H. Loquens, 1980. Comparison of the effects of nitrogen fertilizer on the yield, nitrogen content and quality of 21 different vegetable and agricultural crops. Journal of Agricultural Science, Cambridge, 95: 471-485.

Kahn, B.A., P.G. Shilling, G.H. Brusewitz \& R.W. McNew, 1991. Force to shear the stalk, stalk diame- 


\section{EFFECT OF NITROGEN ON YIELD AND QUALITY OF BROCCOLI}

ter, and yield of broccoli in response to nitrogen fertilization and within-row spacing. Journal of the American Society for Horticultural Science 116: 222-227.

Kowalenko, C.G. \& J.W. Hall, 1987. Effects of nitrogen applications on direct-seeded broccoli from a single harvest adjusted for maturity. Journal of the American Society for Horticultural Science 112: 9-13.

Neeteson, J.J. \& W.P. Wadman, 1987. Assessment of economically optimum application rates of fertilizer N on the basis of response curves. Fertilizer Research 12: 37-52.

Shelp, B.J. \& L. Liu, 1992. Nutrient uptake by field-grown broccoli and net nutrient mobilization during inflorescence development. Plant and Soil 140: 151-155.

Sieling, E.R.M. (Ed.), 1992. Nitrogen fertilization guidelines for arable crops and field vegetables (in Dutch). Informatie en Kennis Centrum Akker- en Tuinbouw, afd. Akkerbouw en Groenteteelt in de Vollegrond, Lelystad, $30 \mathrm{pp}$.

Steur, G.G.L. \& W. Heijink, 1991. Soil map of the Netherlands. General conceptions and classifications (in Dutch). Staring Centrum, Wageningen, 65 pp.

Thorup-Kristensen, K., 1993. Root development of nitrogen catch crops and of a succeeding crop of broccoli. Acta Agriculturae Scandinavica, Sect. B, Soil and Plant Science 43: 58-64.

Toivonen, P.M.A., B.J. Zebarth \& P.A. Bowen, 1994. Effect of nitrogen fertilization on head size, vitamin C content and storage life of broccoli (Brassica oleracea var. Italica). Canadian Journal of Plant Science 74: 607-610.

Uhte, R., 1990. Auswertung von Stickstoffdüngungsversuchen bei Gemüse mit dem Linear Response and Plateau Modell. Gartenbauwissenschaft 55: 247-251.

Vierveijzer, H.C., A. Lepelaar \& J. Dijkstra, 1979. Methods of analysis for soil, sewage, crop and liquid (in Dutch). Instituut voor Bodemvruchtbaarheid, Haren, 261 pp.

Zebarth, B.J., P.A. Bowen \& P.M.A. Toivonen, 1995. Influence of nitrogen fertilization on broccoli yield, nitrogen accumulation and apparent fertilizer-nitrogen recovery. Canadian Journal of Plant Science 75: 717-725. 